удк 657.01

\title{
Михайло Лучко
}

\section{ФІЗИЧНА ТЕОРІЯ БУХГАЛТЕРСЬКОГО ОБЛІКУ: ОКРЕМІ ПИТАННЯ ДОСЛІДЖЕННЯ}

Предметом дослідження є теоретико-методологічні засади бухгалтерського обліку як науки. Закони економіки неодноразово розглядалися вченими в діалектиці протягом багатьох століть. Під час ії становлення виникло чимало ортодоксальних наукових шкіл, котрі об'єднані спільною ідеєю щодо розвитку та моделі фуункціонування. Протягом тривалої пори економісти різних країн світу працювали над тим, щоб зрозуміти закономірності господарських і соціальних процесів, вивести та пояснити економічні закони, використовуючи набуті людством знання і досвід.

Метою статmі є вивчення можливостей застосування методик, які використовуються для пізнання природничих наук до економічних вчень, які придатні для пояснення сутності бухгалтерського обліку. Завданням дослідження є розробка методики практичного застосування методів фрізики до вивчення економіки, виявлення взаємозв'язку між понятійними апаратами бухгалтерського обліку та фрізики. В процесі дослідження використано загальнонаукові й спеціальні методи дослідження, зокрема, моделювання, алгоритмізацію, формалізацію, узагальнення, порівняння, аналогію, системний підхід.

Обгрунтовано можливості та перспективи застосування законів фрізики для пояснення економічних явищ і процесів, і зокрема такоїіх важливої інформаційної основи, як бухгалтерський облік. Визначено взаємозв'язок бухгалтерського обліку з фізикоматематичними науками через використання формалізованого опису його об'єктів, розаляд з точки зору позиціонування обліку як специфічних знань людини, трактування методів обліку (зокрема, балансового) крізь призму алгоритмізації та паралелізму з фрізичними законами (наприклад, закону збереження енергії), встановлення інформаційної ієрархії стану і поведінки активів, капіталу та зобов'язань підприємства, розгляд залишків рахунків з позиції відповідної алгоритмізації та обгрунтування доцільності розвитку фрізичної природи бухгалтерської теорії. Вказано на відмінності балансового методу від закону збереження енергії (енергія в замкнутій системі є сталою, що унеможливлює спостереження процесу надходження чи створення нової енергії в замкнутому просторі). Обірунтовано висновок про позитивний вплив еконофрізики на фрункціонування економіки, доцільність ії застосування для точнішого дослідження економічних процесів, проведення якіснішого економічного аналізу показників діяльності підприємства.

Ключові слова: еконофрізика, балансовий метод, бухгалтерський облік, моделювання. JEL M40; M41

(с) Михайло Лучко, 2017. 
М. Лучко

Фізична теорія бухгалтерського обліку ...

Постановка проблеми. Проаналізовано базові категорії фрізики та економіки. Дослідження проведено на основі вивчення закону збереження енергії та балансового методу, визначено основні спільні й відмінні ознаки між економічним і фрізичним понятійними апаратами.

Аналіз останніх досліджень та публікацій. У вітчизняній та іноземній фахових літературах в значній мірі приділяється увага питанням організації, методології та методики бухгалтерського обліку. Поряд із цим проблеми, котрі складають предмет наукової розвідки, на думку автора, не виокремлено та не досліджено в достатній мірі.

Невирішені раніше частини загальної проблеми. Фізична теорія бухгалтерського обліку в науковому середовищі не розглядається предметно. Автором здійснено спробу можливостей застосування засад фрізичного закону збереження енергії з метою пояснення одного із основних методів бухгалтерського обліку - балансового.

Мета дослідження. Мета статті полягає у теоретико-методологічному обґрунтуванні можливостей застосування законів фізики для пояснення економічних явищ, у тому числі й бухгалтерському обліку.

Виклад основного матеріалу. Більшість економічних фоормулювань, аксіом, суджень і категорій, в тому числі подібних, таких, як праця, гроші, ціни, фрінанси, прибуток, відноситься до типу формалізованих, ймовірнісних та повселюдних, однозначно таких, котрі прийнято називати подібними, які чинять спротив прямому, точному, правильному, єдиному, однозначному їх тлумаченню. Однак, на нашу думку, це не позбавляє їх сенсу і не перешкоджає загальному використанню. Економічні закони або закономірності певного періоду розвитку та історичної ієрархії певної країни носять здебільшого якісний характер, трактуються досить загально. Вважаємо, що використання теоретичних положень економічної науки, досягнутої нею протягом еволюційного розвитку продуктивних сил та виробничих відносин, у дійсності застосування пов'язане з рядом труднощів і вимагає професійної оцінки; тому тут підходять усі засоби: наявні елементи фізики, хімії, астрономії, інших природничих наук, поглиблених знань, практики. Повноцінну економіку пізнати нелегко навіть за допомогою економічної науки, але уникати завідомо обманливих, хибних, перекручених уявлень, явних неточностей можна і потрібно. Для цього щонайменше не слід приймати удаване, на перший погляд, за підсумкову істину; треба глибше усвідомлювати характер і природу подій [5].

Ще донедавна економіку відносили лише до соціальних наук, оскільки люди, що беруть пряму участь в ній, мають очевидний вплив на більшість її процесів. Для того, щоб їх розгадати, досить вербального опису або нескладних математичних навичок. Та з урахуванням окремих чинників, деякі природознавчі науки також можна віднести до категорії “соціальних наук", адже кадри одночасно мають вплив на хід суспільного життя. При цьому за законами логіки явища, що виникають у науках природознавчого характеру, можна описати як словами, так і викласти за допомогою фрормул. В результаті таких спостережень виникло багато проблем стосовно економічних фрактів, їх інтерпретації та методів дослідження. В ході розвитку наукових шкіл та фрормування наукової думки посилилась необхідність в мотивуванні та якісній інтерпретації процесів та принципів, що $€$ основою економіки. Прийнятні наявні методи досліджень наукової думки такої впевненості та обґрунтованості не давали, тому науковці розпочали пошуки сучасних підходів до опрацьовування економіки та її питань. Формування новітніх доктрин та 
стратегій, які б дозволили відповісти на запити та розв'язати економічні проблеми, дозволило поширитись новим науковим напрямам та течіям. Хотілося б приєднатися до наукових думок професора Р. Хайлбронера: “Економісти першими погодяться, що від їх дисципліни не доводиться чекати прогнозів, які б хоч скільки-небудь наближалися за своєю точністю до тих, що дають технічні науки, медицина або астрономія ... Більш того, функції, що описують економічну поведінку, на відміну від тих, що описують "поведінку" зірок або частинок, несуть на собі відбиток волевиявлення або інтерпретації. Саме з цим пов'язана невизначеність всіх соціальних теорій; адже зміна очікувань під впливом сигналів, які ніде, крім як у голові економічного агента, не реєструються, може навіть знак поведінкових функцій змінити на протилежний” $[4,5]$. Так що економіка в її сучасному поясненні - це, з одного боку, наука чисел, розрахунків, обчислень, числових показників, що визначаються з тим або іншим ступенем достовірності, а з іншого, - наука гіпотез, суджень, вірогідних припущень, гіпотетичних думок, висновків, тверджень. А отже, її важко віднести до точних наук і чекати натомість відповідних результатів.

Вперше еконофізика як наука в наукову літературу була ведена у середині 90-х рр. XX cт. американським фрізиком X. (Гаррі) Юджином Стенлі. Еконофрізика - це наука, що застосовує методологію дослідження фрізичних явищ до аналізу економіки та економічних процесів. Широкого ж застосування термін "еконофрізика" набув вже у 1997 р. після симпозіуму, організованого І. Кондором та Я. Кертісом, що відбувався у Будапешті. Становлення такого напряму пов'язане з приходом у науку фрізиків, що запропонували новий підхід до вирішення економічних проблем. Як згадувалося нами вище, основою понятійного апарату економіки виступав вербальний метод, а не фрізико-математичні моделі. Спробуємо надати економічними законам більш наукового та формалізованого вигляду. Для цього застосуємо категорії фізики в порівнянні із опорними категоріями економіки. Результати дослідження оформимо у вигляді таблиці 1. Первині категорії фізики-маса, шлях та час порівнюється з такими економічними категоріями, як: вартість в грошовому вираженні, кількість продукції в натуральних одиницях та час. За допомогою них синтезуємо вторинні категорії без необхідності їх доведення.

\section{Окремі категорії фрізики та економіки}

Табличя 1

\begin{tabular}{|c|c|c|}
\hline $\begin{array}{l}\text { Основні показники } \\
\text { фізичних досліджень }\end{array}$ & $\begin{array}{l}\text { Окремі показники } \\
\text { економічних досліджень }\end{array}$ & $\begin{array}{l}\text { Окремі розрахункові } \\
\text { показники }\end{array}$ \\
\hline Маса фрізичного тіла $-m$ & \multirow{2}{*}{$\begin{array}{l}\text { Вартість у грошовому } \\
\text { вираженні-K }\end{array}$} & Швидкість: $v=S / t$ \\
\hline Шлях -S & & Прискорення: $a=v / t$ \\
\hline \multirow[t]{4}{*}{$4 \mathrm{ac}-t$} & \multirow{2}{*}{$\begin{array}{l}\text { Кількість } \quad \text { продукції } \\
\text { натуральному вимірнику }-N\end{array}$} & Продуктивність: $P=K / t$ \\
\hline & & Економічне прискорення: \\
\hline & \multirow[t]{2}{*}{$4 \mathrm{ac}-t$} & $R=P$ \\
\hline & & Ціна: $K / N$ \\
\hline
\end{tabular}

Джерело. Сформовано автором.

Як бачимо із таблиці 1, в економіці наявні кількісні категорії, а це означає, що для їх переведення в фізичний формалізований вигляд потрібно використовувати певні індекси. Застосування формалізованого понятійного апарату кардинально змінить процес 
М. Лучко

Фізична теорія бухгалтерського обліку ...

моделювання економічних законів та систем, запровадить використання нових підходів в ході економічного моделювання. Ще від початку існування людської цивілізації управління пов'язане із знаннями людини. Людина творить знання, управляє ними, використовує їх та передає в майбутнє. Управління знаннями є певними науковим пошуком в системі наук про управління, що тісно пов'язані з інформатикою та теорією штучного інтелекту (рис.1).

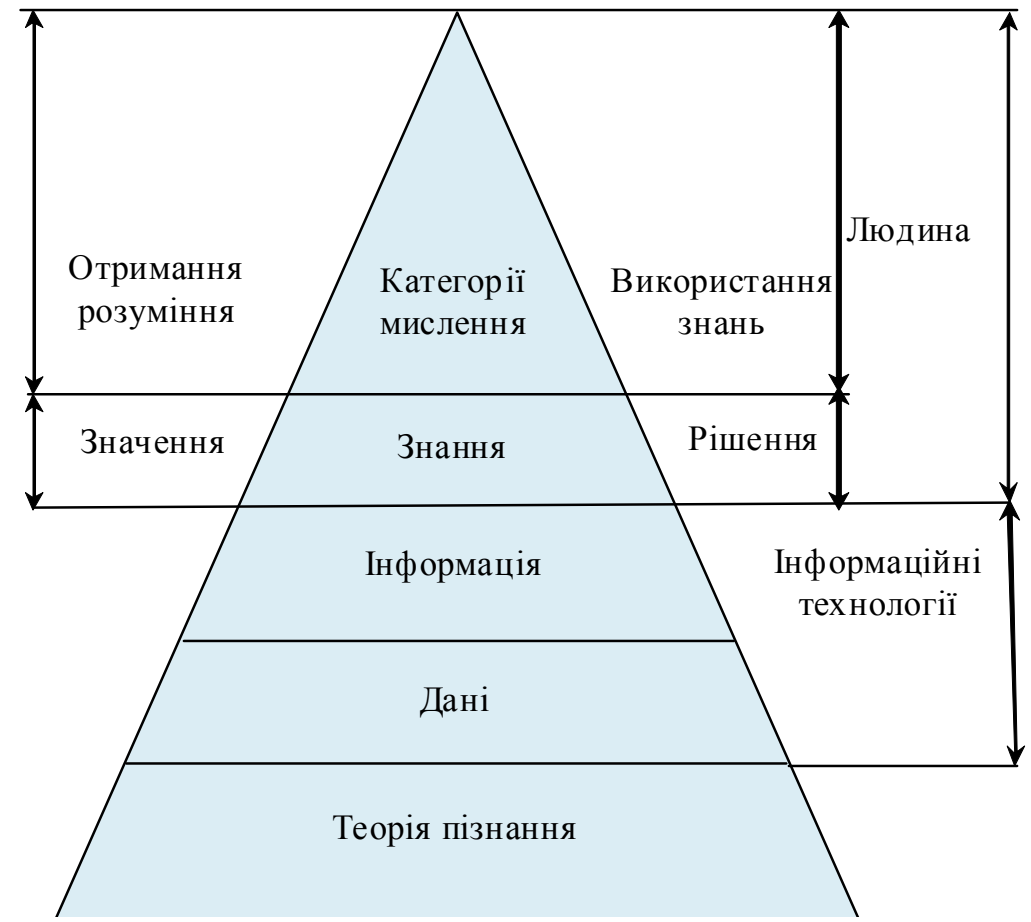

Рис. 1. Теорія пізнання в процесі створення та використання знань людини Джерело. Сформовано автором.

Бухгалтерський облік як самостійна економічна наука $є$ практичною суспільною діяльністю людини. Він накопичує, групує і систематизує факти господарської діяльності, а тому стає інформаційною базою, яка використовується для управління бізнесом. Сьогодні бухгалтерський облік це насамперед складна, створена знаннями, інтелектом та свідомістю людини система виміру, реєстрації, збору, обробки, аналізу і представлення даних про активи, капітал та зобов'язання підприємства під впливом господарських подій [2, с. 21].

Аналізуючи вищенаведене, констатуватимемо, що бухгалтерський облік як функція управління це, перш за все, знання людини. Знання технічного та управлінського персоналу, керівного менеджменту про стан і поведінку активів, капіталу та зобов'язань під впливом господарських подій на усіх рівнях ієрархії підприємства. Неможливо не виділити при цьому й господарські процеси як об'єкти бухгалтерського обліку, а саме: процес створення суб'єкта господарювання, процес його діяльності (постачання, виробництво та збут) і процес припинення його діяльності як суб’єкта господарювання. Саме під час цих процесів й відбуваються господарські події, які впливають на стан та поведінку активів, капіталу та зобов'язань. 
На базі цих знань під впливом господарських подій формується інформаційна ієрархія стану і поведінки активів, капіталу та зобов'язань підприємства-дані, інформація, знання людини, процес управління. При цьому кожен рівень додає певні властивості до попереднього рівня і базується на ньому.

Більшість вчених-економістів стверджують, що проблеми, викликані тими чи іншими процесами, можна ефективніше вирішити, якщо вчасно їх спрогнозувати. Прогнозування $€$ функцією управління, що передбачає економічне життя суспільства. Одним 3 найважливіших важелів виступає обліковий процес та його організація. На перший погляд, облік не має нічого спільного з природничими науками, зокрема з фізикою, але якщо дослідити дане питання в ширшому розумінні, то ми можемо побачити, що облікова система в своїй основі має таке саме підґрунтя, як і фізичні процеси, що відбуваються в природі повсякденно. Поясненням цього може слугувати один з основних законів фізики - закон збереження енергії. Його зміст полягає у тому, що енергія зберігається у замкнутій системі, тобто перетворюється з однієї форми в іншу, але не зникає. Повна механічна енергія, збережена в системі, дорівнює сумі потенційної та кінетичної енергії. Це можна відобразити за допомогою такої формули:

$$
E=E_{\text {потн. }}+E_{\text {кін. }}
$$

де $\mathrm{E}$ - повна енергія; $\mathrm{E}_{\text {потн. }}$ - енергія потенційна; $\mathrm{E}_{\text {кін. }}$-енергія кінетична.

Сам ж закон можна відобразити таким чином:

$$
E_{\text {потн. }}+E_{\text {кін. }}=\text { const }
$$

Спробуємо перенести принцип дії даного закону в площину бухгалтерського обліку. Для кожного підприємства господарська діяльність - це безперервний процес, в результаті якого активи та капітал переходять з однієї форми в іншу. Це можна спрощено відобразити загально відомою формулою кругообігу капіталу:

$$
\Gamma-\mathrm{T}-\Gamma^{\prime \prime}
$$

Кругообіг капіталу - рух промислового капіталу у сфері виробництва і обігу, в процесі якого він набуває трьох функціональних форм (грошової, продуктивної, товарної) і проходить три стадії (обмін - виробництво - обмін). Кругообіг промислового капіталу виражений формулою: товар, отриманий в результаті кругообігу капіталу, відрізняється від товару, купленого на першій стадії, якістю, зовнішньою формою та більшою вартістю. Безперервність кругообігу передбачає, що капітал без затримки переходить з однієї функціональної фрорми в іншу та одночасно існує в усіх трьох формах. Безперервне повторення кругообігу капіталу утворює оборот капіталу.

Це означає, що активи в процесі виробництва дають приріст капіталу, зберігаючи при цьому в новоствореному продукті свою вартість. Стосовно бухгалтерського обліку як функції управління, ми можемо бачити, що основою його побудови виступає ця ж сама замкнута система крізь призму відображення господарських операцій шляхом подвійного запису на рахунках обліку та зведення інформації із застосуванням балансового методу.

Відомо, що балансовий метод має два різновиди. Одним із них є сальдовий метод, що дозволяє спостерігати зміну результативного показника, визначивши та врахувавши вплив останнього із факторів. Даний метод $є$ найбільш поширеним, та одночасно застосовується у плануванні діяльності підприємства, оскільки він дозволяє оперувати не тільки фрінансовими показниками та оцінювати їхню динаміку, але й здійснювати такі ж аналітичні процедури з показниками в натуральному їх вираженні. 
М. Лучко

Фізична теорія бухгалтерського обліку ...

При визначенні кінцевого результату за звітний період на активному рахунку використовують такий алгоритм:

1) протягом місяця за дебетом та кредитом такого рахунку реєструють фракти здійснення господарських операцій;

2) в кінці звітного періоду підбивають підсумки за дебетом та кредитом активного рахунку;

3) далі визначають залишок на кінець звітного періоду на відповідному активному рахунку. Залишок на такому рахунку визначають таким чином: до залишку на початок періоду за рахунком, що аналізується, додають обороти за дебетом та віднімають обороти кредитові. Процес визначення кінцевого залишку (сальдо) за звітний період на окремому активному рахунку можна відобразити за допомогою такої формули:

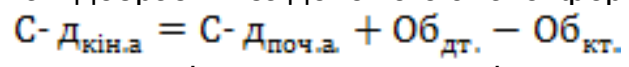

Такий алгоритм застосовують і для розрахунку кінцевого залишку на пасивному рахунку. Єдиною відмінністю $€$ те, що до початкового залишку на пасивному рахунку (C$\mathrm{A}_{\text {кт }}$ ) додають відповідно кредитові обороти та віднімають дебетові. Даний алгоритм знайшов своє відображення в такій формі:

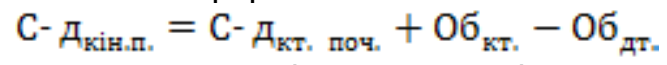

За результатами проведених розрахунків, на активних і пасивних рахунках складається оборотно-сальдова відомість за певний період, у якій спостерігається основне правило балансу, а саме активи підприємства дорівнюють пасивам підприємства.

Такий розподіл дозволяє сорормувати чітку картину про ресурси підприємства та показує постійність та безперервність руху ресурсів підприємства в замкнутій системі подібно до того, як і енергія, яка рухає фізичними процесами, в повсякденному житті (табл. 2).

\section{Порівняльний аналіз балансового методу і закону збереження енергії}

\begin{tabular}{|c|c|}
\hline \multicolumn{2}{|c|}{ Основні показники } \\
\hline $\begin{array}{l}\text { Балансовий метод (активний рахунок): } \\
\text { - } \text { залишок на початок - С-дпоч. } \\
\text { - надходження - Обдт } \\
\text { - вибуття - Обкт. } \\
\text { - } \\
\text { залишок на кінець - С-дкін. }\end{array}$ & $\begin{array}{ll} & \text { Закон збереження енергії: } \\
-\quad \text { повна енергія - E } \\
-\quad \text { потенціальна енергія - Епотн. } \\
-\quad \text { кінетична енергія - Екін. }\end{array}$ \\
\hline$C-\partial_{n \circ 4}+O \sigma_{\partial m}=C-\partial_{K i H}+O \sigma_{k m}$ & $E_{n o m}+E_{\text {KiH }}=$ const \\
\hline 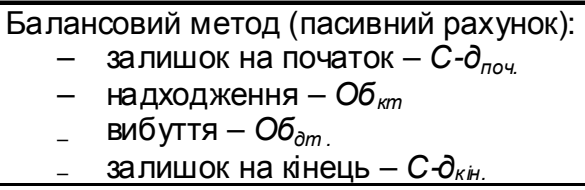 & $\begin{array}{ll} & \text { Закон збереження енергії: } \\
-\quad \text { повна енергія - E } \\
-\quad \text { потенціальна енергія - Епотн. } \\
-\quad \text { кінетична енергія - Екін. }\end{array}$ \\
\hline$C-\partial_{\text {nо }}+O \sigma_{\partial m}=C-\partial_{K i H}+O \sigma_{k m}$ & $\mathrm{sm}+E_{K i H}=$ const \\
\hline
\end{tabular}

Таблиця 2

Джерело. Сформовано автором.

Основними відмінностями балансового методу від закону збереження енергії є те, що енергія в замкнутій системі $є$ сталою, тобто постійною, і ми не можемо спостерігати безпосередньо процес надходження чи створення нової енергії в замкнутому просторі. Щодо бухгалтерського обліку, то ми можемо деталізувати процес надходження нових ресурсів та їх вибуття. Але існує безперечно обліковий період. Це дає нам можливість 
спостерігати безперервність облікового процесу та його замкнутість, незважаючи на те, що в цій системі відбуваються постійні зміни ресурсів. Зазначений порівняльний аналіз дав можливість провести наукову розвідку можливостей застосування методів фізичних досліджень притаманних закону збереження енергії фрормування та обґрунтування теоретичних положень бухгалтерського обліку як функції управління та економічної науки.

Висновки та перспективи подальших досліджень. Беззаперечним є такий підхід, що кожному, хто приступає до вивчення бухгалтерського обліку або поглиблює свої знання в ньому, необхідно усвідомити, що від цієї науки не можна вимагати або очікувати того, чого вона не може дати в принципі в силу своєї природи.

Еконофрізика як вчення $є$ одним із перспективних напрямків розвитку економіки та економічного моделювання господарських процесів. Для ефективнішого застосування даної науки необхідно узгоджувати основні поняття та категорії фрізики й економіки. Також можна відзначити, що еконофізика вплинула на функціонування економіки та її процеси досить позитивно, адже ії застосування дає нам можливість точніше дослідити усі економічні процеси, провести якісніший економічний аналіз діяльності підприємства. Як вбачається з наведеного, балансовий метод в теоретичному плані відповідає закону збереження енергії. Тому, на нашу думку, впровадження та розвиток такого напрямку науки як еконофізика зможе покращити та вдосконалити теоретичні засади бухгалтерського обліку. Не претендуючи на повну наукову виключність думок, що викладені нами, ми вважаємо, що їх реалізація в практиці наукових досліджень, надасть новий поштовх до розвитку теоретичних засад бухгалтерського обліку.

\section{Список використаних джерел}

1. Дубовиков М. М. Эконофизика и анализ фринансовых временных рядов / М. М. Дубовиков, Н. В. Старченко // Эконофизика. Современная фризика в поисках экономической теории / под ред. В. В. Харитонова и А. А. Ежова. - М. : МИФИ, 2007.

2. Лучко М. Р. Невизначеність та ймовірнісність господарських операцій:до питання бухаалтерського обліку / М. Р. Лучко // Науково-практ. вид. “Незалежний аудитор”, 2013. - № 5 (III). - C. 15-23.

3. Лучко М. Р. Питання консолідованої фрінансової звітності в контексті реформування бухгалтерського обліку в Україні /М. Р. Лучко // "Фінанси України”, 2006. - № 8. - С. 75-83.

4. Райзберг Б. А. Экономика слов, чисел, рассуждений и мнений / Б. А. Райзберг. [Электронный ресурс]. -Режим доступу : http://www.elitarium.ru/jekonomika_slov_ chisel_rassuzhdenij_mnenijj/.

5. Хайлбронер Р. Л. Философы от мира сего. Великие экономические мыслители: их жизнь, эпоха и идеи [Электронный ресурс]/Р. Л. Хайлбронер. -Режим доступу : http://www.ereading.club/bookreader.php/149225/Haylbroner_Filosofy_ot_ mira_sego.html.

6. Luchko M. R. Accounting in Ukraine under implementation of the European legislation : monograph / Under the guidance of Doctor of Economics, Professor Mykhailo Luchko // Ternopil : TNEU, 2017. - 243 pages.

7. Luchko M. R. Balance sheet method of accounting and energy conservation law 
[Електронний ресурс] Accounting and the accounting profession in the century of challenges" : consacrat Zilei Profesionale a Contabilu lui, Edicia a 6-a, 5-6 Aprilie 2017, mun. Chi_inu / co m._t.: Grigore Belostecinic [et al.]. - Chi_inu :S. n. , 2017 (Tipogr. "Arv a Color"). -31-37 P. - Режим доступу : $h$ ttp://ase.md/files/catedre/cae/ conf/conf_aprilie_2017.pdf.

8. John J. Murphy Technical Analysis of the Futures Markets: A Comprehensive Guide to Trading Methods and Applications / New York Institute of Finance. - APrentice-Hall Company, 1999.

9. Mantegna R. N. and Stanley H. E. : Scaling Behaviour in the Dynamics of an Economic Index. In: Nature. Band 376, 1995, p. 46-49.

10. Bachelier L. Theory of Speculation (Translation of 1900 French edn) / P.H. Cootner (Ed.) // The Random Character of Stock Market Prices, The MIT Press, Cambridge. 1964. P. 17-78.

\section{References}

1. Dubovikov M. M. Ekonofizika i analiz finansovykh vremennykh riadov [Econophysics and analysis of financial time series]. Moscow, 2007 [in Russian].

2. Luchko M. R. Nevyznachenist ta ymovirnisnist hospodarskykh operatsii: do pytannia bukhhalterskoho obliku [Uncertainty and probability of business operations: to the matter of accounting]. Naukovo-prakt. vyd. "Nezalezhnyi audytor" - Research and practice publication "Independent Auditor", 2013, No. 5 (III), pp. 15-23 [in Ukrainian].

3. Luchko M. R. Pytannia konsolidovanoi finansovoi zvitnosti v konteksti reformuvannia bukhhalterskoho obliku v Ukraini [The issue of consolidated financial statements in the context of the accounting reform in Ukraine]. Finansy Ukrainy - Finance of Ukraine, No 8, 2006, pp. 75-83 [in Ukrainian].

4. Raizberg B. A. Ekonomyka slov, chysel, rassuzhdenyi y mnenyi [Economics of words, numbers, rationale and opinions], from http: //www.elitarium.ru/jekonomika_slov_ chisel_rassuzhdenij_mnenij]/[in Russian].

5. Khailbroner R. L. Filosofy ot mira sego. Velikie ekonomicheskie mysliteli: ikh zhizn, epokha i idei [The worldly philosophers. The great economic thinkers: the lives, times and ideas], from http://www.ereading.club/bookreader.php/149225/Haylbroner_Filosofy_ ot_mira_sego.html [in Russian].

6. Luchko M. R. Accounting in Ukraine under implementation of the European legislation: monograph. Ternopil: TNEU, 2017, 243 p. [in English].

7. Luchko M. R. Balance sheet method of accounting and energy conservation law. Chi_'in'u, 2017, from http://ase.md/files/catedre/cae/conf/conf_aprilie_2017.pdf [in English].

8. John J. Murphy Technical Analysis of the Futures Markets: A Comprehensive Guide to Trading Methods and Applications. New York Institute of Finance: Prentice-Hall Company, 1999 [in English].

9. Mantegna R. N., Stanley H. E. Scaling Behaviour in the Dynamics of an Economic Index. Nature 376, 1995, p. 46-49 [in English].

10. Bachelier L. Theory of Speculation (Translation of 1900 French edition). The Random Character of Stock Market Prices, Cambridge, 1964, pp. 17-78 [in English].

Редакція отримала матеріал 25 вересня 2017 р. 